\title{
The philosophy of the Model in Islamic Education
}

\author{
Leila Rahimi ${ }^{1}$, Ladan Esmailian Khamseh ${ }^{2}$ \\ ${ }^{1}$ Professor of Islamic Azad University and Payame Noor University, Karaj, Iran \\ ${ }^{2}$ Email: ladanesmailian1995kh@yahoo.com
}

\section{ARTICLE INFO}

\section{Keywords:}

Model

Teaching

Training,

Growth \& Efflorescence,

Quran \& Tradition

(Sunnah)

\begin{abstract}
Education plays an important role in the worldly life and the Hereafter of the human being and in order to achieve a better society which provides the grounds for personal development and social areas, benefitting from different methods of training is quite useful. In other words, education, in fact, in a way, is a change of attitude, and because and attitudes has a close relationship with the insights and worldview and the ontology of the person, it enjoys a certain stability. To change this attitude one should implement programs in this complex process do that the person to bring him close to whatsoever is the purpose of their creation and development. Therefore, one of the factors in the development of human beings is appropriate education by using direct or indirect methods so that human can benefit from a sound and appropriate insight and attitude. Among the methods that addresses this important issue is the model approach and in other words, emulating others. The model training method is one of the comprehensive approaches and is very effective in training. It's being comprehensive is because it is applicable in all affairs and stages of life and since it offers the content of education objectively and practically; it is very effective in conveying concepts and teaching educational programs.
\end{abstract}

\section{The Meaning and Concept of a Model}

Lexically, the term 'model' is as plan, paradigm, sample, example, model and so on, but idiomatically and in various sciences it has different and, of course, close. In the field of education, the literal meaning of model, is in complete conformity with the lexical meaning and is ascribed to a model or a sample or a model of the form or objects or an instance of conduct. In Islamic sources a paradigm is mentioned as having at least three meanings; exemplar, following and imitating and tradition and method. The Persian equivalent is model and example which, of course, has a more extensive semantic meaning (23, p. 25).

In this article, model means an individual, by whom the current of education is guidance and directed and has an effective role in the formation of character, behavior, social encounters, fostering and creating behavioral norms and.... In fact, a vast portion of training becomes orderly based on the model and paradigm of the system and therefore considering the factors of the model as a benchmark in training is very important. In Islam, when a model is mentioned one's memory is quickly transferred towards the perfect human being.

A complete human being means a model human being, a supreme human being or a sublime human being. Understanding the complete human, a model human being from the perspective of Islam is obligatory for Muslims in the sense that it is considered to be a model, model or a paradigm, namely if we want to be a complete Muslim. Islam will be the perfect human to

* Corresponding Author E-Mail Address: Leila_rahimi747@yahoo.com 
make the education and training of human perfection, we need to know how to be perfect human, perfect human face to face is spiritual.

As the religion of Islam aims to make a complete human being and become complete human beings under Islamic education and training, we need to know how a complete human being is, what the spiritual image a complete human being is like, what kind of aspect the spiritual aspect of complete human being is and what the characteristics of a complete human being are like so as to make ourselves and our community with such characteristics $(18$, p. 96).

In the course of education -from the perspective of other schools of thought- also, the model and paradigm play the main and principal role. For example, concerning the duties of the teacher, idealists believe, without a doubt, that in any society, with any system, the teacher plays an important and valuable role.

In different educational situations the teacher can easily give much assistance to their students in strengthening the power of good judgment and consolidating moral character and in the recognition and appreciation of human values $(9$, p. 171).

The model approach is an approach whose foundation is based on the modeling and providing concrete and practical examples. In this approach, the teacher tries to be an example of exemplary behavior and deliberately expose the student to good deeds in order to provide the conditions necessary for him to emulate and imitate (23, p. 27).

\section{The Meaning and Concept of Education}

Education, with its limited concept, consists of inspiring, delivery and the transfer of knowledge to the minds of students. Thus, the teacher acts within the circle and the sphere of his responsibilities, in such a way that the student remains silent in his presence and receives his inspirations and words. The responsibility of training is in equipping students with various limited information and knowledge which is often unclear for the students themselves.

Teaching with such a limited concept itself, is an inadequate and incomplete act, because it is only concerns one human area (that consists of his mind). But it must be said that proper teaching consists of the effort that teachers should, under its auspices, awaken enthusiasm and desire of knowledge and practice and its concerns of the two in the souls of students (5, p. 12).

Educating and tutoring alone is not teaching. Because the teacher is not a factor who only teaches children, rather he is a factor who must cause children to learn, to learn whatever they need to learn, so that they can improve better, faster and more passionately and grow. Teaching to learn is the teacher's most important task. The students' learning is an open and clear window from inside which he can clearly see, test and improve his professional skills. Therefore, the best tutoring takes place when the educator (teacher) to set the learners (students) free to learn themselves, let them struggle with the abilities, to gain individual or group experience, and eventually find themselves and finally to gain "self-esteem" and "selflearning" not "belief in the teacher." (8, p. 8).

\section{The Meaning and Concept of Training}

Lexically, training means increasing, excelling, making something excellent quality and precious. In the latter meaning training means the quitting of extremes and pushing towards moderation. Another meaning for training is to purify. From here it becomes clear that the term training is synonymous with the term purification, because purification has the same meaning that the meaning and concept of training also has (4, p. 247).

Then the educator is someone who in the light of being trained, the educator helps them grow and brings abundance so, in other words, he (the educator) makes him (the student) valuable. It is obvious that this growth and abundance is in the light of changes that the educator creates within him. The deeper and more fundamental these changes are, these developments 
will be stronger and more valuable $(7, \mathrm{p} .8)$. Of course it is also necessary to make this point that training means stimulating the various talents and strengths of a human being and its development that must be combined with the efforts and endeavors of the student, in order to attain his own relative maturity, to achieve the amount of stamina and ability necessary. These various talents and strengths and the quality of their applications are found in the light of regular and organized actions and begins his prosperity and growth under the supervision of educator and fosterer (5, p. 10).

However, the issue of training, is the human soul that can voluntarily issue beautiful and praiseworthy or evil and obscene deeds $(12$, p. 48) Therefore, training and development can be physical, mental, moral, and affected by a variety of factors such as the home, family, school, religious and moral communities and ... (5, p. 38).

Nevertheless, the task of training is an ongoing reality. Namely, after talent and strengths found in humans become activity; even so that same activity in comparison to another perfection that a person has not attained will be in the form of a faculty. Thus, the task of training consists of "Converting strengths into activities» and this task will continue until the last moments of people's lives. In contrast, some say the true educator is someone who can extract the human being's overflowing energy. He claims that human existence is similar to mines containing diamonds and rubies, but a precious mine which has been extracted $(7, \mathrm{p}$. 10).

According to Shahid Motahhari, training is comprised of two parts; a part of which has a developmental aspect and another part of training which means developing, monitoring the blossoming of talents and capabilities such as developing the faculty of will and the mind or the development of the body and training means building, witnessing the formation of a type of feature in the human being $(19, \mathrm{p} .191)$.

In his opinion, the main theme of training is the human being and he has two aspects: the human body and soul each of which fall under the subject of training (18, p. 556). Of course, it should be noted that part of the body is the subject of training which is within the limit of talent and building or modifying it is possible. Otherwise, that part of the body that has been formed and became actualized and not subject to change, will not be the subject of training $(16$, p. 20).

\section{The Difference between Education and Training}

Education cannot be considered to be two synonymous terms that are completely equal in every way in concept and reference are equal. In other words, these two terms are not such that each of them implies the concept that the other term also implies. These two words are different in some ways and are related in others. Training has a broad and enduring meaning, while the word teaching in regards to its context (to the extent that it is a device and factor for training) does not exceed it. Therefore, teaching is a part of the training or a device from among its devices. In other words, along the path of performing his duty of teaching the teacher tries to fill the minds of students with information and knowledge. However, the educator strives through training- to open the way for the human being's talent and potential from within him for discussion and exploration. Training is not limited to the area of intellect of the student alone, because knowledge and understanding is not everything nor is it the most important thing training, rather knowledge and understanding are secondary in importance and sensual aspects such as conscience, will, morality, good conduct with people of a society and so on are just some of the topics that the broad aspects of the concept of training can accommodate within itself.

Training always pays attention to the higher goals and valuable moral and social purposes. But the purpose of teaching (in its limited concept) consists of acquainting students with limited affairs and mental exercise in them. Training as it is such right now is common only 
prepares the human being for occupation knowledge and victory in its examination, while he needs training, the human being wants to guided concerning the principle and purpose of life and the productiveness of characteristics and light tendencies in the human being so that he can live in peace with others while enjoying a healthy, successful and prosperous life. Therefore, training realizes goal to make a human being out of the human being himself so that he can benefit from being a human being (before he is a means and a tool for earning his livelihood) (5, p. 13).

For this reason, in Quranic themes and Islamic traditions, when training is mentioned, training is in first place and then talk about teaching is brought up: "Recite in the name of your Lord who created. Created man from a clinging substance. Recite, and your Lord is the most Generous - Who taught by the pen - Taught man that which he knew not" (1- Surat Al'Alaq [The Clot (96)]: Verse 1-5). A point that can be found in these verses and several other verses, of course, with a little reflection that attracts attention, is the priority of the word "ربّك" = Your Lord" to the word "علّم = taught knowledge", the Holy Quran with its heavenly revelation during these verses notes the supreme importance and priority of education.

In short, given these verses we can reach this conclusion that the difference and points between appropriate and desirable education is enormous and all our mild complaints and reproofs come from here. Because in the vast majority of schools and scientific centers and mankind has content himself with teaching, while enough attention has not been and will not be paid to this issue. Often the teacher himself teacher does not understand the distance between these two truths often the conditions and circumstances of today's human society is such that the teacher cannot, while teaching students, to help in the flourishing of various talents and strengths and put in the path of virtue and has to spend time filling the minds of students with knowledge and things that must be memorized and finally and limit his efforts in his victory and passing of courses. However, it should be noted that if training is separated from the grounds for the downfall and destruction of mankind will surely be provided. So cry of real educators of all ages have warned humanity and has attacked educators especially scholars of Islamic education of noetic teachings hard and those such as the Second Martyr (Zayn al-Din al-Juba'i al'Amili), Avicenna, Khaje Tusi, Farabi and other scholars of the Islamic world given the importance of the issue of training and its role in the protection and safeguarding of humanity and spirituality and finally the survival of humanity, have been devoted books or parts of their books to this issue.

The Infallible Imam says:

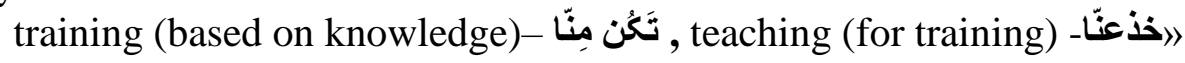
Thus the educational sciences are those that inculcate "becoming": or mediate for "becoming"; or prepares a person for "becoming". "Becoming" is a principle and a destination and the difficult and time consuming part of the matter that members and limbs begin to function in "becoming", the pillars of existence (thinking, intellect, heart) all function: those members with these elements would become subordinate and coordinated, until training is achieved; a comprehensive training, all developments true, doctrinal and perceivable and visionary and ethical and practical and personal (21, p. 392).

\section{The Philosophy and Importance of Education}

In expressing the importance of education, suffice it to say that realization of the nature of man depends upon his education and the care that is given under the auspices of education concerning mankind of human actions is a necessary condition for a man to reach the stage of perfection. Man can only become a human being through education. If he is subject to proper training, he will have the temperament of an angel and if he is deprived of its blessings, not only will his potential talents and resources be wasted, rather he will most likely regress to the level of beasts and also be reduced to levels lower than that. 
In fact, the human being is the only creature who is responsible for the quality of their lives. The human being is a thinking creature, has the ability of discerning, has free will and is autonomous and the improvement of circumstances and his salvation depends on how he regulates the individual and collective programs of his life and how he implements them. In the meantime, as long as he has not reached the age of maturity, others should prepare a life for him that is unique to the dignity of a creation. By seizing this opportunity one should help him so that he will be prepared for a life based on moral autonomy for which the overall value of his life depends on its quality, because a human being's performance, in the course of life with independence means the manifestation of his humanity in real social life depends on to what extent he has been able to realize the truth of his existence in light of an education from which he benefits in his childhood and adolescence and pave the way in the pursuit of perfection in the rest of his life, $(10,30)$.

The spread of education and providing the supplies thereof, is very effective for protecting the interests of individuals and society, because educating a make a person successful in the community and enhances the level of his social and economic life, and the attaining welfare and comfort and equips the human being with skills and emotions and an appropriate way of thinking (where he can visualize his place in the society) and opens the way to victory to him and he can make better effort in order to solve personal problems, and try to improve the life of the community and if their was education the worth of the people in society would not be known and were deprived of achieving their objectives (5, p. 220).

When a child steps into the world he should see people at his side who, in addition to mental health and self-moderation he wishes that children, sincerely face facts. Gradually, the child while facing facts will pay intellectual and theoretical attention. Then take him with them throughout life and help him deal correctly and plausible issues, with events and ... till the child learns correct way to act, courtesies, behaviors, socializing, compliances, observations, rights, to learn explanation and understandings and meanings like these. With sincere expression an educator presents all of these methods to the child: looking correctly, finding the values of judgment, applying these values, making the correct judgments, giving correct opinions; thus presenting all of these to the child. Therefore, the direction movement in this course includes: "training" for children and teens, "perfection" for the young person who has been trained, "guidance" to the older person who has addressed ontological perfection (21, pp. 83-84).

\section{The Model in the Holy Quran and Tradition (Sunnah)}

Islamic education stems from the source of revelation and accordingly, it is considered to be religious, divine and spiritual and since the subject of education is a human one and its aim is becoming and helping other in becoming an ideal human being, while he is seeking his beginning and origin, at the same time he places the principles and foundations that have found roots in the beginning and believes them to be fixed, so that he can create the necessary changes in the body of human beings who want something new and cover his figure with the proper clothing.

Education wishes to bring about a change in human beings, so it is necessary for the educator to know his players and the essence of the human being and his nature and every school and, in a way, let every expert of anthropology introduce him. And since the changes that need to occur in humans are, themselves, designed and offered programs in the form of opinions, assumptions and decisions that have a source and a trajectory for this current and is extreme; each and every school of education, in some way, offers a special program. Islam is a training school for human beings; it believes in the beginning and the end and has announced a program and a method of educational measures that it believes should be put into action for 
him. In Islamic training the initiator is God, and He is the first and last of the universe (2, pp. $62,63)$ and says:

$$
\text { 》هو الاول و الآخر و الظاهر و الباطن و هو بكل شئ عليم): }
$$

Translation: He is the First and the Last, the Manifest and the Hidden, and He has knowledge of all things (1- Surat al-Hadid (Iron [57]): Verse r).

Prophet Mohammad was directly connected with the source of revelation and was being educated and trained by God. Our infallible leaders were also indirectly being educated and trained under divine supervision. Muslims are all educated and trained under the supervision of Prophet Mohammad and the Infallible Imams and have grown and developed in accordance with the principles of Islam. In the following holy verse, the matter of divine education and training of the children of Abraham has been raised:

$$
\text { الصلوه و و ايناء الزحق و يعقوب نافله و كلا جعلنا صالحين و جعلنا هم ائمه يهدون بامرناو اوحينا اليهم فعل الخيرات و اقام }
$$

Translation: And We gave him Isaac, and Jacob as well for a grandson, and each of them We made righteous. We made them imams, guiding by Our command, and We revealed to them the performance of good deeds, the maintenance of prayers, and the giving of zakat (poor due), and they used to worship Us (Surat al-Anbiyā' [The Prophets (21): Verses 72 and73].

In regards to the Prophet Mohammad having received a divine education, the Quran says:

$$
\text { 》و انزل الله عليك الكتاب و الحكمه و علمك ما لم تكن و كان فضل الله عليك عظيماي: }
$$

Translation: Allah has sent down to you the Book and wisdom, and He has taught you what you did not know, and great is Allah's grace upon you (Surat al-Nisā' [Women (4): Verse 113].

One of the basic features of the Islamic education and training is considering the importance of intellect and its role in the development of individuals' character. Imam Musa Kazim (PBUH) said: "O Hashem, God has sent the prophets and messengers for us to think about Him. He who has more knowledge is more receptive (accepted) and he who has more reason, is more aware of God and is wiser about the will of God and he whose intellect is more complete -his degree is greater in this world and the hereafter. O Hashem, truly, God has two purposes over people: a disclosed purpose and a hidden purpose. But the disclosed purpose is the prophets and leaders but the hidden purpose is that intellect "(13, Vol. 1, p. 25)."

\section{Different forms of model training}

Model training can be accomplished in various ways, such as modeling, the processing of the model and de-modeling which are explained briefly below:

\section{Giving a role model:}

The purpose of modeling is to provide positive and real role model meaning that the models that can be found outside the mind of the researcher and are visible which this itself could be provided in two ways: A) Providing a model of the self: In this approach the educator virtually reflects desirable traits in their behavior. Perhaps the best example for model training is that the educator is, in the position of action, a perfect example for his students, as the student sees the words or actions of the educator deed train the trainers in action as one (in unison) and experience theory and practice. B) Providing a model for others: In this approach, the educator tries to introduce those who have a model aspect to the students. In this method he acts in two ways: In the first approach, the educator arranges his program in such a way that the student can see the model live and see him doing good things or the result of a character and trait of good. The second approach is that the educator introduces the desired exemplaris and models that are seemingly hidden from the educator's view, however 
in the past, it had an external reality and the tradition and methods of their lifestyle in society has enjoyed a life of prosperity and special brilliance and explains the personality characteristics and lifestyle of the individual and society to him. After the demise of Prophet Mohammad (PBUH\&HP), Imam Ali, the Commander of the Faithful (PBUH) refers to this kind of model training and with the introduction of Prophet Mohammad (PBUH\&HP) and his recognition of characteristics, says: Follow the guidance of your Prophet, as it is the best guidance and follow his traditions (Sunnah) and method for it is the best of guides (23, p. 29).

\section{Model -processing}

The purpose of this approach is to present hypothetical and fictitious models. In this approach, the educators are taken into consideration as good models, and focuses on explaining and describing its features it prepares ground in such a way that the student is drawn to imagine and visualize a model or a scene and an event.

He sometimes does this by telling an imaginary story or a tale the stories and he achieves this goal by stating characteristics, signs and symptoms. In both approaches the more the educator is an artist and has more skills in processing desired models the more successful he will be. The description of the "men of understanding", "prosperers", "servant of the All-Merciful", "pious" and so in the Holy Quran is of this type, as the Holy Quran, by expressing the characteristics of each of these classes, is at the top in giving his audience a model $(23,30)$.

\section{De-modeling}

In this method, negative role models and characters are depicted as a kind of disenchantment and negative attitude towards those role models arises in the student.

In such cases, naturally, a phenomenal positive attitude towards mutual models is a something normal. In other words, in such cases, the educator can create a type of positive attitude in their opposite direction "from whom did you learn politeness, from the rude" By providing negative models and describing their adverse consequences, in the student. From the words of Imam Ali (PBUH) it can be concluded that the recognition of types of guidance depends on the understanding deviation and temptations: "And know that you will never recognize salvation unless you recognize its bestower and you will never be loyal to the Quran, unless you recognize the apostates ... and you will never recognize misguidance unless you recognize guidance and you never recognize piety unless you recognize who exceeds the boundaries of virtue .... . In these sentences, Imam Ali (PBUH) understands one of the ways of recognition, in general, to be the recognition of events and recognize of the desired model is no exception to this rule. This kind of model training is executable in two forms. The first form is that the educator trying to keep that student away from those models in the form of expression and properties and signs of negative models of negative symptoms. The second form is that the educator, with direct prohibition, prevents the student from association and companionship with bad models. What is important in this approach, which requires precision and skill of the students given the sensitive work. The educator must not provide a negative model in such a way that it seems desirable to the student and as a consequence attempt to copy that model (23, p. 31).

\section{Features and Functions of the Model in Education}

Various affairs, customs and specific duties form the examples and the model towards the students or educators of which the center of all of these is the correct proper adjusting of the relationship of the leader and teacher with his disciple and or the student. In this part we refer to this state of affairs:

Competence and Worthiness of a Person in Education

1-Bodily and Physical Properties:

2-Insight and awareness: 
-Academic proficiency to the curriculum:

-Psychology

-The desire to discharge the duty of teaching and devotion to teaching

-Awareness of science of ethics, politics and policy and religious sciences

3-Good disposition and humility:

\section{The Mission of the Teacher and the Importance of his Character in Model- making}

one of the most important features of the educator, is self-building before training others: That he wants to be the leader of the people and invite them to follow a path, before he wants to teach others, make himself the audience and train and indoctrinating himself and before he wants to train people with his own language, he trains himself through practice and a good ethical method and correct morals. That he educates and disciplines himself, for respect and reverence, is more is more worthy than someone who is merely a teacher and educator of others $(20,85)$.

\section{The Duties of the Educator}

The educator has duties and obligations that if he is not familiar with them and not implement them he cannot to be fruitful in the field of education. Among these tasks are the following:

1-Knowledge of the ways and means of education

2-Recognizing the young (mentalities and challenges)

3-Considering the Personality Development of the Educator

4-Easiness and flexibility in training

5-Tolerance and attention to specific emotions of each student

\section{Conclusion}

The modeling method is one of the most effective approaches in the field of education. In this method, learning takes place primarily through direct observation which is one of the most stable forms of learning. The learning process, such as understanding and conveyance of the message to a student is accomplished faster and with ease. Error and mistakes in learning will be less. As long as the student observes human models, he discovers his own human abilities and capabilities and tries to perfect them and through this his self-esteem is strengthened and man goes towards his perfections more confidently and his motivation increases towards reaching his observed perfections.

Of course, the effectiveness and efficiency of each method depends on the implementation of its principles and regulations. These regulations often have general aspects the observance of which is necessary in all the methods - such as complete knowledge of the educator to the educational techniques and also awareness of the student's characteristics and ... which we have discussed to a necessary extent and it sometimes has specific aspects so the specific method which becomes a complete success -such as associating the modeling method with logic and reasoning and avoid nonsensical training imitations, closeness and cooperation in different aspects between the model and the one who accepts the model, which accelerates modeling and replications process, presenting a variety of models and indirect models, etc., which have been mentioned in this paper.

Finally, it is worth mentioning this point that the modeling method, unless some other methods which are applicable to a specific environment or for a particular age or grade, is usable and effective in different environments and different age groups and for the scope of the application of this method has gained a special significance. On the other hand, the scope of application of this method includes all aspects of life and it can be argued with certainty that there is no condition, behavior or action that could not be covered by using this method to institutional it, therefore everyone, especially the educational authorities using these 
methods to enhance people's ability to think and reason and intellectual independence, especially young people so that through the power of analysis and the lack of blind imitation of others to be extended in people's minds and human society moves on the path of perfection and progress to.

\section{Reference}

Aboutalebi Ahmadi, M. T. Self-esteem and its Relationship with Success, Tehran, Nazir Publishing Company, 1378

Amoozegar, Mohammad Hossein, An Introduction in training from the perspective of Islam, Qom, Salman Farsi Publishing Company, 1370.

Bandarrigi, Mohammad, Munjid al-Tolab, Tehran, Islamic Publications, 1372.

Ghaemi Moghaddam, Mohammad Reza, Model Method in Islamic Education, Ma'refat Magazine, September 1382, No. 69.

Hojjati, Mohammad Baghir, Islam and Education (Vol. 1 and 2), Tehran, Islamic Culture Publishing Office, 1368.

Hojjati, Mohammad Baghir, Teaching and Learning Practices in Islam, Islamic Culture Publishing Office, 1367.

Kulayni, Muhammad ibn Ya'qub ibn Ishaq, Usool Kafi (The Sufficient Book) Shirazi Bazar, Islamia Seminary Publications, Bi Ta.

Mahdizadeh, Hussein, Islamic Teachings Regarding the Imitation of Models (with an Emphasis on the Youth), Ma'refat magazine, July 1382, No. 67.

Majlesi, Mohammad Baghir, Bihar al-Anwar, Tehran, Lithography, 1305 AH.

Maleki, Hasan, Education for Children and Adolescents from the Viewpoint of Imam Khomeini, Tehran, Madrase Publishing, 1379.

Mashayekhi Rod, Shahabuddin, Educational Thoughts of Professor Shahid Morteza Motahhari, Qom, Center of Islamic Research Broadcasting, 1390.

Mazloomi, Rajab Ali, A Step in the Direction of Islamic Education (three volumes), Tehran, Afaq Publishing, 1362.

Motahhari, Morteza, A Collections of Morteza Motahhari's Notes, Speeches and Interviews about Islamic Revolution, Tehran, Sadra, 1368.

Motahhari, Morteza, Collections, Qom, Sadra, 1371.

Motahhari, Morteza, ten words, Tehran, Qom, Sadra, 1367.

Motahhari, Morteza, The Diary of Morteza Motahhari, Tehran, Sadra, 1379.

Muhaddith Qomi, Hajj Sheikh Abbas, Safine al-bahar, Tehran, Lithography, 1355 AH.

Ra'ouf, Ali, Teaching for Learning, Tehran, Madrase Publishing, 1378.

Rashidpour, Majid, Introduction to Islamic Education, Tehran, Parent-Teacher Association, 1375.

Shariatmadari, Ali, Principles and Philosophy of Education, Tehran, Amir Kabir Publications, 1366.

Shokouhi, Gholam Hossein, Education and its Sages, Mashhad, Razavi Publications, 1372.

The Holy Quran.

The Second Martyr, Moniyeh al-Morid fi Abad al-Mofid and al-Mostafid, Tehran, Bi Ta Publications, 954.

Tousi, Khaje Nasiraddin, Ethics of the Nazarene, Mojtaba Minoo (Ed.), Tehran, Khwarizmi Publications, 1356. 